\title{
Benefits of Sasi for Conservation of Marine Resources in Raja Ampat, Papua
}

\author{
Paulus Boli $^{1 *}$, Fredinan Yulianda ${ }^{2}$, Ario Damar ${ }^{2}$, Dedi Soedharma ${ }^{3}$, Rilus Kinseng ${ }^{4}$
}

\begin{abstract}
${ }^{1}$ Graduate School of Bogor Agricultural University, Dramaga Main Road, Campus IPB Dramaga, Bogor, Indonesia 16680
${ }^{2}$ Department of Aquatic Resources Management, Faculty of Fishery and Marine Science, Bogor Agricultural University, Academic Ring Road, Campus IPB Dramaga, Bogor, Indonesia 16680

${ }^{3}$ Department of Marine Science, Faculty of Fishery and Marine Science, Bogor Agricultural University, Academic Ring Road, Campus IPB Dramaga, Bogor, Indonesia 16680

${ }^{4}$ Departement of Communication Science and Community Development, Faculty of Human Ecology, Bogor Agricultural University, Academic Ring Road, Campus IPB Dramaga, Bogor, Indonesia 16680
\end{abstract}

Received May 14, 2014/Accepted August 29, 2014

\begin{abstract}
Residents of Raja Ampat, Papua, have been practicing sasi for generations to manage local marine resources. Recognizing its importance for marine resource conservation, efforts have been made to integrate sasi into current conservation management approach. This study was carried out with 3 objectives: (1) to define and elaborate sasi; (2) to examine the benefits of sasi for conservation of marine resources; and (3) to evaluate the change of sasi in the context of conservation. Multi-method approaches were employed to collect data from local communities in Dampier Strait District MPA in 2 separate sampling periods. Results indicated that sasi in Raja Ampat could generally be categorized into samson or kabus which basically reflect different aspects such as location, type of commodity, implementing ceremony, period of closure, the influence of monsoons, and communal ownership. The benefits identified included the increase in target fish production, the lowered level of exploitation, the improved recovery of fish stocks, and the increase in the local people's income. From the modern conservation management point of view, it was obvious that sasi could help protect and sustain marine biological resources. Therefore, it is essential to incorporate sasi into modern conservation management practices and vice versa.
\end{abstract}

Keywords: sasi, traditional management, benefits, conservation

*Correspondence author; email:bolipaul@yahoo.com, tel: +62-8124845665

\section{Introduction}

As in other regions in Indonesia, Raja Ampat's coral reefs are severely threatened by various activities of marine resource utilization by local residents and migrants. Some of the issues that threaten the existence of coral reefs in this area are fishing with explosives and potassium, overfishing and the influx of nutrients and sediments into waters due to deforestation and land clearing for settlement (Larsen et al. 2011). The effort made by the local government to prevent the depletion of marine resources in Raja Ampat is by employing good fishing management such as applying restrictions on fishing equipment and areas. In addition, the Raja Ampat District Government and the Ministry of Marine Affairs and Fisheries of the Republic of Indonesia since 2006 have initiated the establishment of regional marine protected areas. The problems that can still be found in the management of marine-based conservation in this region are: (1) the role of the government is more dominant than the community's role, (2) the central government often ignores the customary rights of local communities, (3) management of protected areas is based only on modern science, disregarding local wisdom (local knowledge and technology) (Damanik et al. 2006).

One form of local wisdom in Raja Ampat which has the potential for conservation is sasi. Sasi is the spatial and temporal closure of an area of natural resources in the form of agricultural fields (gardens), forests, coral reefs, and fishing locations (Thorburn 2000). The area closure is intended to give a chance for certain animals or plants to grow and thrive in order to produce more crops (Mansoben 2003). The results of the research conducted by McLeod et al. (2009) in this area has demonstrated that the villages which still maintain the practice of sasi have better marine resource conditions compared to villages which have already abandoned the practice. This study is supported by a previous study by Hickey \& Johannes (2002) and Novaczek et al. (2001) which showed that the spatial and temporal closure of the waters for trochus harvesting for certain lengths of time in coastal villages have been far more profitable than continuous trochus harvesting practices.

Management of natural resources based on this custom has received significant attention as a potential conservation 
management in the Indo-Pacific region (Cinner et al. 2007). There are serious efforts from the government, nongovernmental organizations (NGOs), and academia to integrate marine conservation initiatives with customary practices that restrict the use of resources (Cinner et al. 2012). This initiative is based on the reasoning that until now modern marine resource conservation management often fails to become a product of government policies that meet the expectations of the community. Instead, natural resource management undertaken by indigenous communities has been quite successful in maintaining the sustainability of fishery resources by applying the knowledge and technology that is passed down from generation to generation (Cinner \& Aswani 2007). Efforts to adopt the traditional management of marine resources into modern conservation have succeeded in improving the condition of coral reefs in Oceanic countries (Aswani et al. 2007).

Questions that will be attempted to be answered in this paper are: how can the sasi management system effectively maintain sustainability of fishery resources and how can it be resilient in the face of changing social, economic, and cultural conditions in Raja Ampat? Based on these research questions, the purpose of this article are: (1) to describe sasi in Raja Ampat, (2) to assess the benefits of sasi for conservation of marine resources, (3) to assess changes in sasi in the context of modern conservation.

\section{Methods}

The Dampier Strait Regional Marine Conservation Area has an area of 336,000 ha, which includes the Dampier Strait and the Sagawin Strait (Figure 1). These waters are the gateway for the mass of water from the Pacific Ocean water moving towards the Indian Ocean. The current flows very strongly, causing the upwelling phenomenon that brings with it nutrients for marine life. This condition is the reason why Raja Ampat waters have a rich fish and coral biodiversity. The waters in this conservation area are a habitat for manta rays and are a grouper spawning site, as well as a habitat for marine mammals such as dugongs, whales, and dolphins. Dampier Strait has now become the foremost tourist destination in Raja Ampat. The population is 9,530 people spread in 7 sub-districts and 36 villages. The majority of the people's level of education is elementary school. The people's livelihoods are dominated by fishing and agriculture, planting potatoes and corn.

The data collected in this study were primary and secondary data. The collection of primary data was through interviews with purposive sampling and distributing questionnaires to respondents and field observations. The respondents selected were local residents, community leaders, religious leaders, customary leaders, village government officials, district government officials, and NGO activists. Secondary data were obtained from various agencies in the Raja Ampat Disrict: the Statistics Bureau, the Fisheries and Marine Resources Agency, the Raja Ampat Tourism Bureau, the Department of Transportation, and the Local House of Representatives Secretariat. In addition, data were also obtained from the Conservation International (CI)
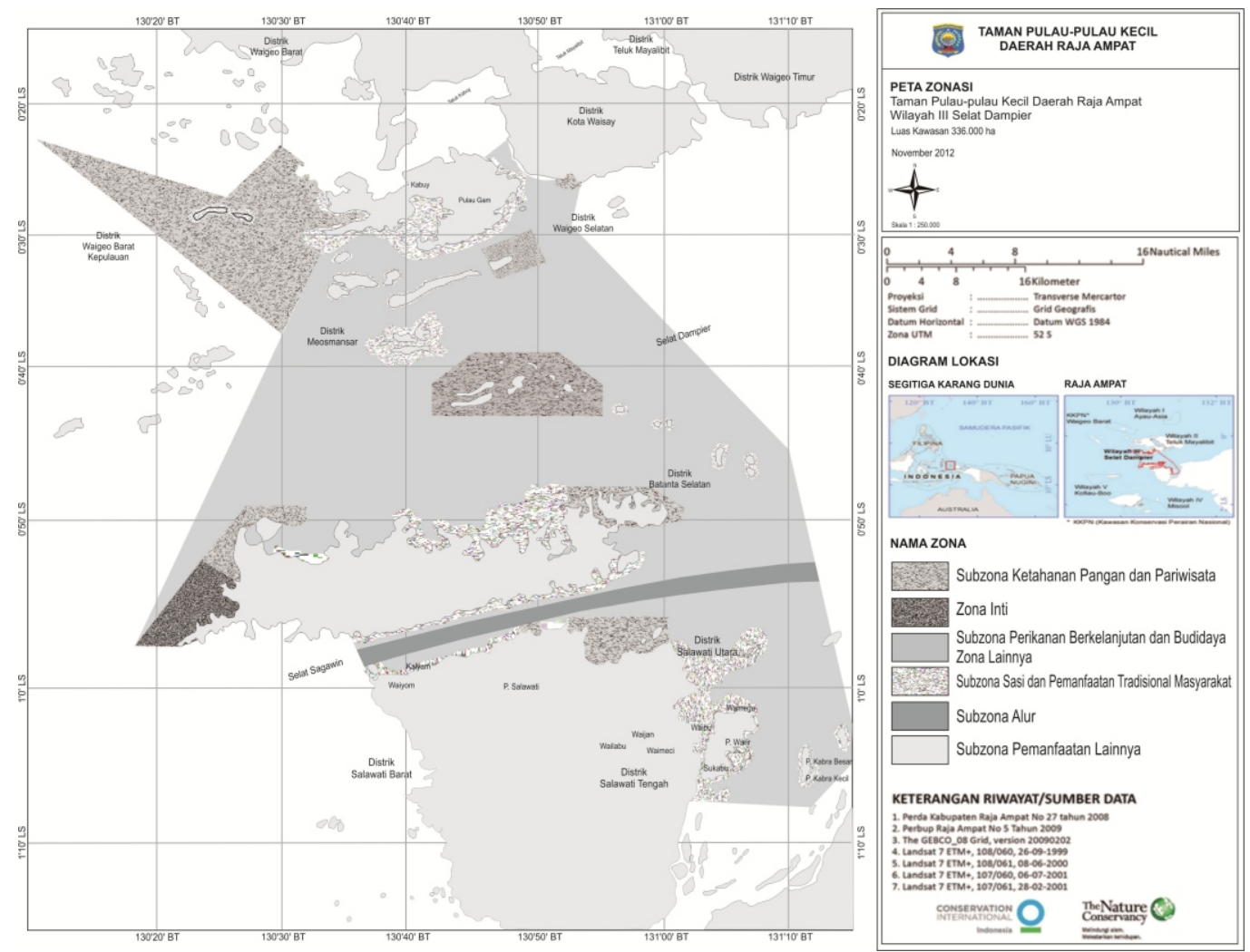

Figure 1 Research sites of the Dampier Strait Regional MPA. 
and the nature conservancy (TNC) NGO Secretariats and the Office of Coastal Affairs in Sorong. The study was conducted in two data-collection stages: August to September 2012 and April to July 2013.

Data analysis All the observation results obtained in this research were analyzed using descriptive statistics. The data obtained were analyzed and displayed in graphs or figures and tables. The description of quantitative data was supported and combined with a review of field notes from interviews and field observations as well as material from secondary data. In addition, an analysis of the situation was done using a contextual approach to explain events in the field. This analysis was important to obtain a complete description of the research location.

\section{Results and Discussion}

The sasi system in Raja Ampat Natural resource management using the sasi system is still found in almost all the villages in the study site. The location of the implementation of sasi is an area of customary ownership of a village or clan groups in the form of bay waters, capes and small islands. Sasi in Raja Ampat is one of the expressions of customary rights of clans (tribes) on marine resources (McLeod et al. 2009). Natural resource management practices like this are also found in the Indo-Pacific region (Lam 1998; Cohen \& Foale 2013). Sasi is an example of a social institution established to safeguard the utilization of natural resources in the form of prohibiting residents from harvesting forest or marine products in a certain place for a certain duration (Mansoben 2003; Adhuri 2013). The final goal of the implementation of sasi for local communities in Raja Ampat is harvesting the marine resources with a higher yield both in quantity and size, as well as generating a large amount of cash revenue (Handayani 2008).

Every ethnic group in Raja Ampat has their own terms for sasi. The Maya people who live in Dampier Strait call sasi kabus, while the Matbat people who dwell on Misool Island call it samson. In other Papua regions such as Biak and Jayapura, it is known as sasisen and tiatiki, respectively (Mansoben 2010). In Kupang, East Nusa Tenggara, the practice of temporary closure of an area is known as lilifuk (Anakotta et al. 2009). Sasi itself is a well-known term in the management of natural resources in the Moluccas (Wahyono et al. 2000). In the Pacific region where the indigenous culture still retains ownership, sasi management is also known as taboo in Fiji (Lam 1998), tabus in Vanuatu (Caillaud et al. 2004), and tambu in Solomon Islands and Papua New Guinea (Foale \& Manele 2004).

The types of sasi found in the Dampier Strait and Raja Ampat in general are shown in Table 1. The types of sasi are each distinguished based on the location, the type of commodity, the institution which performs the ceremony, the closing and opening times, communal tenure (Monk et al 1997; Adhuri 2013), and the influence of the monsoons. Based on the location of the resources, whether they are found on land or at sea, sasi is classified into land sasi and marine sasi. Another type of sasi in Raja Ampat is always associated with a the type of agricultural or aquacultural commodity that has high economic value and is a major source of income for local communities such as coconuts, trochus, sea cucumbers, and lobsters. Therefore, the naming of sasi is tailored to the type of commodity. In addition, based on the establishment ceremony, sasi can be distinguished into custom sasi, if their establishment is based on a customary ceremony, and church sasi, if it is done with a church ceremony.

Other types of sasi known in Raja Ampat are based on the effect of the seasonal winds, customary tenure, and the implementation duration. Strong winds for several months in the waters of Raja Ampat do not allow fishermen to catch fish. This condition is referred to by local people as season sasi and the enactment of sasi will end as the windy season ends. Meanwhile, based on customary tenure system, sasi is distinguished into clan (family) sasi and village sasi. Clan sasi is applied to land owned by the clan usually in form of agricultural fields, whereas village sasi is implemented on an area which is community property of the village, for example, the waters in front of the village. Based on the time of implementation, sasi can be distinguished into temporal sasi and permanent sasi. Temporal sasi is implemented for a short period of time, approximately 3-24 months, whereas permanent sasi is implemented in a longer period of time or in an area that does not have any harvesting time. Permanent sasi is a system adopted from the modern conservation, which is a no-take zone.

The implementation of sasi can be classified into open sasi and closed sasi which can be done by a customary or

Table 1 The types of sasi found in the Raja Ampat

\begin{tabular}{ll}
\hline Aspects & Types of sasi \\
\hline Location & Coconut sasi $i$ trochus sasi, sea cucumber sasi, lobster sasi \\
Type of commodity & Customary sasi and church sasi \\
Implementing ceremony & Temporal sasi and permanent sasi \\
Closed-open time & Monsoon sasi \\
Influence of the monsoons & Family sasi and village sasi \\
\hline
\end{tabular}


religious ritual or a combination of the two. Closed sasi is closing an area or prohibiting the harvesting biota from a certain area for certain length of time. On the other hand, open sasi is the opportunity to harvest marine resources in an area which was previously closed against resource utilization activities. Sasi is marked with palm leaves which are placed on the beach or Indonesian bay leaf trees which have had all of their leaves sheared off but the branches and twigs left intact and are planted facing the sea in front of the village and on each end of the village. Before the influence of Christianity and Islam, in Raja Ampat, the sasi ceremony was performed by a shaman known as a mirinyo. The sasi ceremony conducted using church rituals are basically the same as custom sasi, differing only in the prayers. The people believe that the prayers or mantras spoken by the priest or the shaman will invoke protection from supernatural powers which will protect the sea and punish violators of sasi with illness that will end in death. It is also believed that the mystical powers will provide food for the marine biota which will make the harvest abundant (Nikijuluw 1994; Mustaghfirin et al. 2012).

Sasi rules may include the types of marine life or fish that may be caught, the type of fishing gear used for harvest, the harvesting time, and number that can be harvested (McLeod et al. 2009). Most of the sasi areas forbid the harvesting of 2 commodities, sea cucumbers and trochus. The fishing equipment allowed in harvesting in sasi locations are only simple fishing equipment such as fishing poles, fish spears, and traditional diving goggles called molo glass. The utilization of fish resources for family consumption and earning cash can only be conducted beyond sasi areas. Catching fish outside of sasi areas must also use environmentally friendly fishing methods.
There is no specific institution or individual who oversees the local regulations in Raja Ampat. The rules are not written, but people are very observant of the rules or agreements made, and they are ready to be given sanctions if they break the rules. Violation of local wisdom will have terrible repercussions for the perpetrators, supernatural sanctions in the form of illness or death. Aside from the punishment above, other penalties can be imposed on sasi violators such as reprimands, monetary fines, confiscation of fishing gear and boats, and exile from the village. So far, sasi rules and sanctions for persons who violate them are still very effective in preventing and deterring violators in Raja Ampat(Handayani 2008).

The benefits of sasi for marine conservation Observations of fish production targets of sasi such as sea cucumbers, trochus and lobsters harvested from the Regional MPA of Dampier Strait until now has not yet been conducted because none of the sasi areas in this MPA have been opened. However, based on interviews and direct observations, there are indications of an increase in the number and size of protected biota. Some species of fish and protected biota such as sharks and turtles that were very rare before the establishment of sasi are now often encountered by fishermen and local residents.

Data about the increased fishery production is shown from the results of the sasi opening in the marine protected area of Kawe in Figure 2. In this picture, it shows that during the establishment the first period of sasi from the year 2007 to 2009 , the number of sea cucumbers harvested by local fishermen was 12 species and 919 individuals. The total weight and average weight of individual sea cucumbers after processing were $88.5 \mathrm{~kg}$ and $0.10 \mathrm{~kg}$, respectively. The

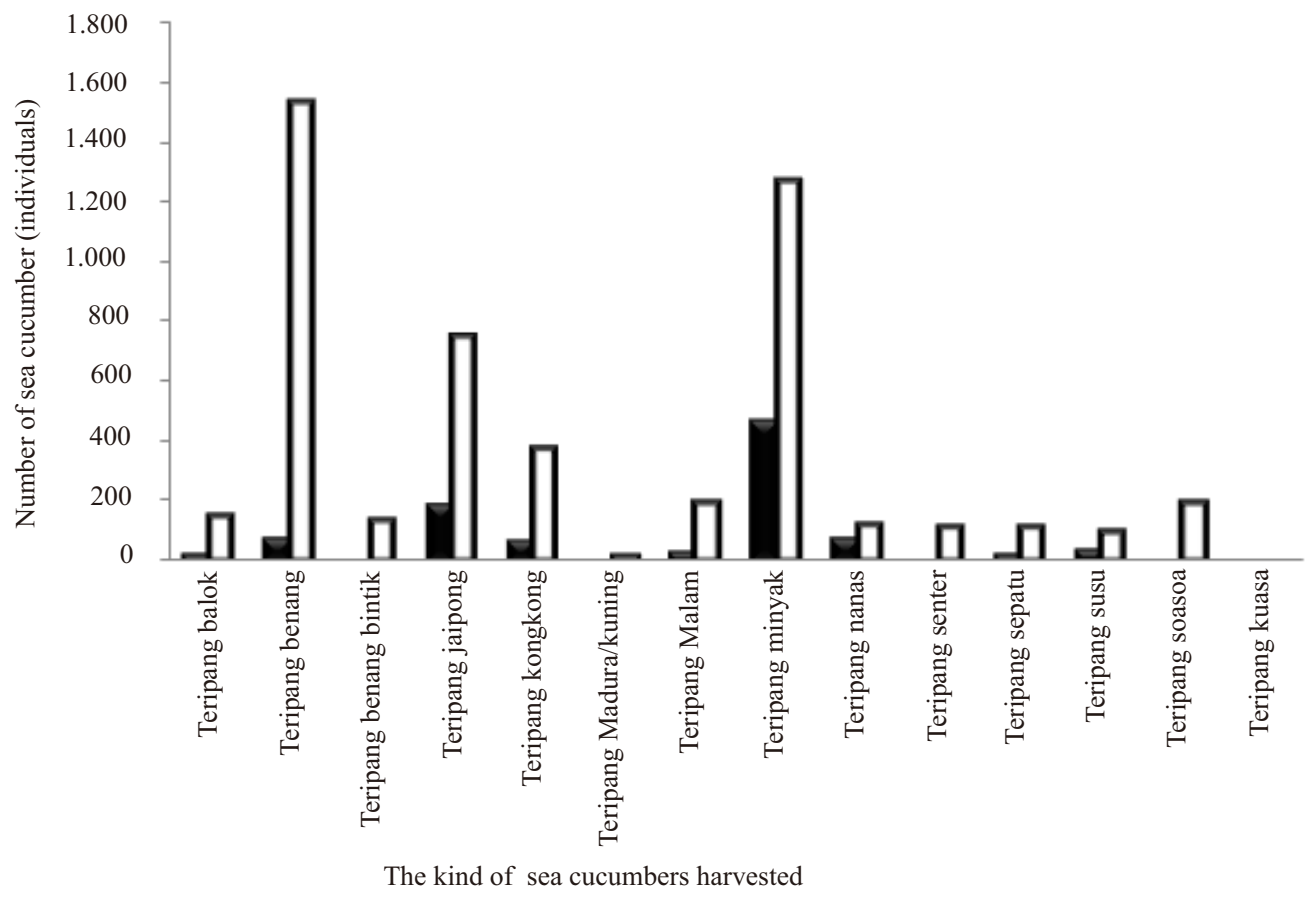

Figure 2 The number of sea cucumbers harvested during Kawe's buka sasi in 2009 and 2012. 
establishment the second period took place between 2009 and 2012 which produced as many as 16 species of sea cucumbers and 5,067 individuals. The total weight and the average weight of individual sea cucumber after processing were $460.5 \mathrm{~kg}$ and $0.09 \mathrm{~kg}$, respectively.

The implementation of sasi rules in an area in the waters of Raja Ampat which was previously overfished has increased production and improved stocks of sea cucumber, trochus, and lobster as well as protected marine biota. This outcome is in line with the opinion of Aswani \& Sabetian (2010) who stated that closed areas have resulted in a threefold fish biomass increase in Vanuatu and a twofold increase in the Solomon Islands in comparison to areas that were not closed. Similar results were shown by Samoilys et al. (2007) who stated that there is a significant difference in the fish population, where it was better in protected waters than in unprotected waters. This outcome was consistent with the high abundance of trochus harvested in the Solomon Islands in an area which was closed for 9 months compared to areas which were not closed (Foale \& Day 1997). This suggests that the sasi management model can be an effective tool to prevent excessive harvesting of fish resources that does not observe resource sustainability principles.

The implementation of sasi also has a positive impact on the trochus stock recovery in Raja Ampat. The observation of trochus stocks in the sasi location in the regional MPA of Kawe, during the open sasi in the 2009 to 2012 period is shown in Table 2. The trochus harvest in 2009 in an area which was closed for 2 years numbered 626 individuals with a total weight of $243 \mathrm{~kg}$, and an average weight of $0.39 \mathrm{~kg}$ individual ${ }^{-1}$. The number of trochus in 2012 increased further when the sasi location was closed one year longer than the previous period. The total number of trochus harvested was 1,285 , the total weight $589 \mathrm{~kg}$, and the average weight $0.46 \mathrm{~kg}$ individual $^{-1}$.

From the production data of sasi in the regional MPA of Kawe, it can be seen from the data for both sea cucumbers (Figure 1) and trochus (Table 2) that there is an indication that the longer an area is closed, the higher the numbers of sea cucumbers and trochus that can be harvested. This fact can lead to the conclusion that a fishery location would produce sustainable resources if it is never exploited. However, this method does not provide a direct economic impact on the local fishermen whose lives depend on fishing unless there are alternative livelihoods. The research by Cohen and Foale (2012) showed that in the Indo-Pacific waters, periodic closures will provide benefits for short-lived and fast growing species with a low fishing level, but it is the opposite for long-lived species with a high level of fishing. Therefore, it is necessary to study the relationship between the length of closing time of the sasi area and the economic value obtained by Raja Ampat fishermen.

The community's enthusiasm in supporting the implementation of sasi in Raja Ampat is based on their empirical experience that before the implementation of sasi, the fisherman's catches were shrinking and more difficult to obtain. This is because of the high level of fish resource utilization due to the rapid population growth, an increasingly open market access, as well as the increasing number of migrant fishermen who catch the fish themselves or buy fish from local fisherman (Johannes 1978). The results of the fisheries research in the Gulf of Kabui, Raja Ampat by Bailey et al. (2008) found that in 1999, the number of migrant fishermen was 20 people and it increased to 250 in 2006. Evans et al. (1999) stated that the decline of fisheries resources in several sasi locations in Moluccas was caused by the population growth and changes in fishing practices. The implementation of sasi in Raja Ampat has had a positive impact, seen through the decline in the number of both local and outsider fisherman who fish in no-take areas. This will assist the improvement of the coastal ecosystem in this area. Campbell et al. (2012) showed that the restriction in the use of fishing nets in the panglima laot indigenous-based management in Aceh successfully reduced habitat damage and maintained fish biomass.

Proceeds from the sale of trochus, based on data for 2 periods of open sasi, showed an increase in the sales value of the commodity as shown in Table 2 . The income value received from the sale of trochus in the period of 2007-2009 was IDR4,854,000 and increased to IDR11,782,144 in the period of 2009-2012. The income received from the sales of the commodity is usually used for constructing public facilities such as the church, village streets, and the boat dock. Another benefit of the implementation of sasi is reducing the cost of management of the protected areas because the local people participate in monitoring and safeguarding their resources. In addition, the success of an area management will provide a bonus in the form an improved nutritional status and health of the local population due to the availability of fish resources (Aswani \& Furusawa 2007). The marine conservation practitioners have agreed that community-based marine protected areas such as sasi can improve food security in coastal communities (Weiant \& Aswani 2006).

Table 2 Weight, number, weight per individual, and the selling price of trochus during Kawe Regional MPA's buka sasi in 2009 and 2012

\begin{tabular}{cccccc}
\hline Year & $\begin{array}{c}\text { Closing time } \\
(\text { year })\end{array}$ & $\begin{array}{c}\text { Weight } \\
(\mathrm{kg})\end{array}$ & $\begin{array}{c}\text { Number } \\
(\text { individual })\end{array}$ & $\begin{array}{c}\text { Weight } \\
\left(\mathrm{kg} \mathrm{individual}^{-1}\right)\end{array}$ & Price (IDR) \\
\hline 2009 & 2 & 243 & 626 & 0.39 & $4,854,000$ \\
2012 & 3 & 589 & 1,285 & 0.46 & $11,782,144$ \\
\hline
\end{tabular}


Sasi in the context of marine conservation in Raja Ampat Efforts to adopt sasi into modern conservation management systems by conserving the marine resources in Raja Ampat started in 2003 through the customary declaration of Tomolol. In 2006, the indigenous people submitted their land to local government to be managed in a marine conservation system. Then in 2009 the local government and Regional House of Representatives issued Raja Ampat District Regulation Number 27 pertaining to the establishment of the regional network of marine protected areas in Raja Ampat region which covers 6 locations: (1) Ayau-Asia, (2) Kawe, (3) the Dampier Strait, (4) the Gulf of Mayalibit, (5) Islands Kofiau-Boo, (6) and South East Misool.

The adoption of the values of sasi in the effort to develop marine conservation in Raja Ampat has had a positive impact on the sustainability of fishery resources in Raja Ampat. These changes occurred because of the success of the NGOs working in Raja Ampat in disseminating conservation benefits for the sustainability of fishery resources to the community and local leaders in this area. An important effort has been done in this adaptation process: the renewal of the sasi culture for the management of marine resources. It can be seen in the adaptation of elements of modern conservation science into the implementation of sasi in the region. Identification results discovered during the study found that as many as 12 sasi elements have changed in terms of the implementation of marine protected areas in the study locations as shown in Table 3 .

The changes in the implementation of sasi in Raja Ampat, if compared to before the establishment of the regional MPA in Raja Ampat, can be classified into 3 aspects which are (1) the areas managed, (2) the institutions, and (3) the management system. The changes to the area aspects and marine resources that are managed in the context of conservation include the size of the area, sasi signs, boundary markers, targeted resources, and the size of the harvest. The changes in the institutional aspects include the increased number of stakeholders and the formation of a supervisory institution. In the aspect of the management system, sasi adapted these elements: purpose, length of time, legal basis, and form of sanctions.

Management of marine resources using a traditional system in general has several weaknesses, for example the limited area, the lack of boundaries, and the target resources are only certain species without any harvesting size limit. Through modern conservation approaches, a much larger area for the implementation of sasi in Raja Ampat is being considered. Prior to the establishment of protected areas, the average size of (temporal) sasi was less than 100 ha, and after the implementation of the conservation area, it exceeded 100 ha. Specifically for food security and tourism zones or permanent sasi zones, it covers an area of more than 100 ha. For example, the food security and tourism zone of Tapor Tamyam in Kampung Yenbuba covers an area of 2,500 ha. The increase in area of about 25 times will ensure all the biota within the sasi can thrive, especially species that have extensive cruising areas such as pelagic fish.

In general, the changes within sasi implemented in Raja Ampat Regional MPA also happened to the biota which is the target of sasi system's protection. Before the establishment of the regional MPA in Raja Ampat, there were 3 species of marine life with high economic value which were protected:

Table 3 Sasi changes in the context of the MPA establishment in Dampier Strait

\begin{tabular}{|c|c|c|c|}
\hline & Sasi elements & Before implementation of regional MPA & After implementation of regional MPA \\
\hline 1 . & Size of area & Small $(<100$ ha $)$ & Large $(>2,500$ ha $)$ \\
\hline 2 . & Sasi sign & Tree, coconut leaves & Information board \\
\hline 3. & Border sign & None & Buoys and site coordinates \\
\hline 4. & Target of resources & Sea cucumbers, trochus, lobsters & All marine biota \\
\hline 5. & Harvesting size & Any size & Complies with science \\
\hline 6. & Purpose of sasi & Collecting more money for building the church & Fish bank and tourism \\
\hline 7. & Institution & $\begin{array}{l}\text { The head of the village, the village representative } \\
\text { body, traditional leaders, and church leaders. }\end{array}$ & $\begin{array}{l}\text { The head of the village, traditional leaders, } \\
\text { and church leaders and conservation } \\
\text { management authorities }\end{array}$ \\
\hline 8 . & Supervision & Local people & Groups of rangers and local people \\
\hline 9. & Enforcement of the rules & Customary sanction & Customary sanction and police \\
\hline & Tutup sasi duration & $6-12$ months & More than 2 years-permanently closed \\
\hline & Buka sasi duration & 3 months & 15 Days \\
\hline & Mechanisms of consensus & $\begin{array}{l}\text { Consensus level of a village or several villages, } \\
\text { usually without documentation }\end{array}$ & $\begin{array}{l}\text { Consensus level of a village or several } \\
\text { villages, documented by collective } \\
\text { agreements by signing an official report } \\
\text { and Board Agreement }\end{array}$ \\
\hline
\end{tabular}


sea cucumbers, trochus, and lobster. The number of species that were protected increased after it was declared as a conservation area. As in the regional MPA of Kawe, the kinds of organisms which are targeted in sasi protection in addition to the 3 types above are giant clams, turtle eggs, fish, and other marine and terrestrial biota. Moreover, modern sasi is equipped with a coordinate system and buoys that clearly mark the conservation areas. According to Dangeubun et al. (2013), one of the causes of failure in the implementation of marine protected areas in Indonesia, especially in Southeast Aru Islands Maluku Province, is unclear area boundaries.

Institutional of Sasi in Raja Ampat has accomodate a limited basis elements from outside the village such as NGOs, tourism entrepreneurs, and universities. NGOs and universities provide advice in managing the of Sasi, while tourism entrepreneurs play a role in the utilization of the area for tourism. According to Berkes et al. 2001, the role of civil institutions such as NGOs have become part of fisheries management. Prior to the enactment of the management of marine protected areas in Raja Ampat, institutional of Sasi is very simple according to the social structure of the community. Sasi proposed and facilitated by community leaders that exist in the village, such as village government, traditional leaders and church leaders. Therefore, by involving civil institutions from outside the community in the management of of Sasi is one solution to maintain the continuity of of Sasi system in this area.

Sasi in Raja Ampat is not equipped with a resourceoverseeing body, which functions: supervise, determine the timing of SASI and arrangements harvest size, as well as the utilization of sale proceeds. SASI management in Raja Ampat conducted jointly by all members of the village community. This differs to the sasi system in Maluku which is equipped with a supervisory agency called Kewang or "rangers" whose job is to supervise and manage sasi areas and the entire terrestrial and marine customary area (Wahyono et al. 2000; Tuhulele 2013). With the implementation of the conservation system in Raja Ampat, the sasi which is implemented in this area is now equipped with a community-based supervision system. The structure of the public monitoring group consists of one supervisor coordinator and as many as 4 members from the local community.

A fundamental change that has occurred to the sasi management system is the inclusion of this system into the Raja Ampat Regional Regulations. Sasi system implementation in Raja Ampat received legal power through the establishment of Raja Ampat District Regulation Number 27/2008. In this regulation, as stated in Chapter I, Article 15, it is declared that in the establishment and conservation management, elements of local wisdom need to be considered. Furthermore, in the draft of the 20 Year Park Management Plan of the Small Islands of Raja Ampat, it was suggested that it be divided into 2 zones associated with the sasi. The zones are: (1) the sasi and traditional utilization zone, and (2) the food security and tourism zone. The sasi and traditional utilization zone is a fishing zone allocated for people who still use traditional tools, with the aim to ensure the sustainability of the livelihoods of traditional fishermen. Whereas the food security and tourism zone is a no-take zone that is reserved for fish and other marine biota breeding, aimed to function as food reserves for the community, and provide economic benefits through marine tourism activities (Mustaghfirin et al.2012).

A formal establishment of sasi areas is very urgent because in the future, its existence will be eroded by the population growth and increased investment into the region. According to Caillaud et al. (2004), the continuity of traditional management in an area is strongly influenced by development, the influence of religion, education, and other cultures. Muehlig-Hofmann (2007) explains that the success of community-based conservation management is largely determined by strong local leaders. While according to Cinner et al. (2007), indigenous resource management institutions are not impervious to population growth and economic modernization; therefore, if the system is to be used as the basis of modern conservation initiatives, it is necessary to filter out the impact of socio-economic transformation.

The sasi system has also adopted modern conservation management concepts by increasing the closing time and shortening the opening time of sasi, and even applying permanent closure of some areas. The closing and opening system approach to conservation is one aspect of sasi management that aims to provide adequate time for the ecosystem to recover itself. The opening-closing system is similar to the temporary closure system in conservation management (Cinner \& Aswani 2007). Prior to the establishment of the regional MPA, area closures lasted for 6-12 months while the area was opened for over 3 months. After the establishment of conservation in Raja Ampat, the closing time was more than 24 months but the opening time was less than 15 days. In the zoning system implemented in the Raja Ampat Regional MPA, there is a food security and tourism zone. The customary zone in Raja Ampat waters which has been declared as permanents sasi areas are areas which have these characteristics: they have a high diversity of coral species, and they are spawning and nursery grounds for fish. The customary community has permanently closed these areas. At the research location, there are as many as 4 permanent sasi which covers $20.77 \%$ of the 336,000 ha of Dampier Strait Regional MPA area.

The success in adopting traditional marine resource management to modern conservation has improved the condition of coral reefs in the Oceanic countries (Aswani et al. 2007). The difference between the concepts and practices of indigenous-based management and modern conservation can lead to the failure of the integration of the 2 systems, but if the difference is understood and respected, the hybrid system has great potential in achieving effective management because: (1) it is highly flexible; (2) it can conserve resources, and (3) it can achieve community goals (Cinner \& Aswani 2007). Results of a study conducted by Cohen and Foale (2011) on the adaptation of customary fisheries management with modern marine conservation the countries in the Pacific region found that indigenous-based management that has adopted modern conservation elements has these characteristics: (1) it is similar to customary closing, (2) it can be managed by local management institutions, and (3) it is agreed upon as a management tool by the government, NGOs, and local communities. 


\section{Conclusion}

Sasi in Raja Ampat is known as kabus or samson and is distinguished by these aspects: the location, the type of commodity, who performs the ceremony, the closing and opening times, the influence of the monsoons, and communal tenure. Sasi, which has been practiced from generation to generation, has a positive impact on the management of marine resources including maintaining the sustainability of fishery resources, recovering fishery stocks, reducing the exploitation rate, and increasing fishery revenue. The existence of sasi in Raja Ampat was adapted due to the establishment of the regional marine protected area in the following aspects: (1) the areas managed, (2) the management institution, and (3) the management system. The existence of sasi all this time has been able to protect the sustainability of aquatic resources due to the high compliance of the Raja Ampat local population to customary rules. In addition, they realize the potential and the benefits which the added values of marine resources could bring through marine tourism compared to capture fishery alone. The sasi management system will be able to survive (is resilient) in the face of social, economic, and cultural changes if the system adopts modern conservation elements such as changing temporal sasi to permanent sasi.

\section{Acknowledgement}

The authors gratefully acknowledge the assistance provided by Albert Nebore, Meity Mongdong, and Nur Hidayat (CI Sorong), Luke Rumetna, Purwanto, and Dheny Setiawan (TNC Sorong), Abraham Goram from Kalabia Foundation, Manuel Urbinas and Syafri from the Office of Marine Affairs and Fisheries Raja Ampat.

\section{References}

Adhuri DS. 2013. Selling The Sea, Fishing for Power: A Study of Conflict Over Marine Tenure in Key Islands, Estern Indonesia. Canberra: ANU E Press.

Anakotta ARF, Bessie D, Anakotta W. 2009. Kajian Kelembagaan Daerah Perlindungan Laut Berbasis Masyarakat dengan Kearifan Lokal di Desa Bolok. Laporan Penelitian Hibah Bersaing. Kupang: Universitas Kristen Artha Wacana.

Aswani S, Sabetain A. 2010. Implications of urbanization for artisanal parrotfish fisheries in the Western Solomon Islands. Conservation Biology 24:520-530. http://dx.doi. org/10.1111/j.1523-1739.2009.01377.x.

Aswani S, Furusawa T. 2007. Do marine protected areas affect human nutrition and health? A comparison between villages in Roviana, Solomon Islands. Coastal Management 35(5):545-565. http://dx.doi.org/10.1080/ 08920750701593394.

Aswani S, Albert S, Sabetian A. Furusawa T. 2007. Customary management as precautionary and adaptive principles for protecting coral reefs in Oceania. Coral Reefs 26:1009-1021. http://dx.doi.org/10.1007/s00338007-0277-z.
Bailey M, Rotinsulu C, Sumaila UR. 2008. The migrant anchovy fishery in Kabui Bay, Raja Ampat, Indonesia: catch, profitability, and income distribution. Marine Policy 32:483-488. http://dx.doi.org/10.1016/j.marpol. 2007.09.010.

Caillaud A et al. 2004. Tabus or not taboos? How to use traditional environmental knowledge to support sustainable development of marine resources in Melanesia. SPC Traditional Marine Resource Management and Knowledge Information Bulletin $17: 14-35$.

Campbell SJ et al. 2012. Avoiding conflicts and protecting coral reefs: customary management benefits marine habitats and fish biomass. Oryx 46(04):486-494. http://dx.doi.org/10.1017/S0030 605312000348 .

Cinner JE, Aswani S. 2007. Integrating customary management into marine conservation. Biology Conservation 140:201-216. http://dx.doi.org/10. 1016/j.biocon.2007.08.008.

Cinner JE, Sutton SG, Bond TG. 2007. Socioeconomic thresholds that affect use of customary fisheries management tools. Conservation Biology 21(6):1603-1611.

Cinner JE et al. 2012. Institutional designs of customary fisheries management arrangements in Indonesia, Papua New Guinea, and Mexico. Marine Policy 36:278-285. http://dx.doi.org/10. 1016/j.marpol.2011.06.005.

Cohen PJ, Foale SJ. 2011. Fishing taboos: securing pacific fisheries for the future? SPC Traditional Marine Resource Management and Knowledge Information Bulletin 28:3-13.

Cohen PJ, Foale SJ. 2013. Sustaining small-scale fisheries with periodically harvested marine reserves. Marine Policy 37:278-287. http://dx. doi.org/10.1016/j.marpol.2012.05.010.

Damanik R, Satria A, Prasetiamartati B. 2006. Menuju Konservasi Laut yang Pro Rakyat dan Pro Lingkungan. Jakarta: Wahana Lingkungan Hidup Indonesia (Walhi).

Dangeubun FDW, Wiryawan B, Mustaruddin, Purbayanto A. 2013 Management effectiveness of Southeast Aru Islands Marine Conservation Area. Jurnal Manajemen Hutan Tropika 19(2):119-127. http://dx.doi.org/10.7226/jtfm. 19.2.119.

Evans SM, Gill ME, Retraubun ASW, Abrahamz J, Dangeubun J. $1997 . \quad$ Traditional management practices and the conservation of the gastropod (Trochus niloticus) and fish stocks in the Maluku. 
Fisheries Research 31:83-91. http://dx.doi.org/10. 1016/S0165-7836(97)00011-8.

Foale S, Day R. 1997. Stock assessment of trochus (Trochus niloticus) (Gastropoda: Trochidae) fishery at West Nggela, Solomon Islands. Fisheries Research 33:1-16. http://dx.doi.org/10.1016/S0165-7836(97)00062-3.

Foale S, Manele B. 2004. Social and political barriers to the use of marine protected areas for conservation and fishery management in Melanesia. Asia Pacific Viewpoint 45(3):373-386. http://dx.doi.org/10.1111/j.1467-8373. 2004.00247.x.

Handayani. 2008. Kajian terhadap bentuk-bentuk kearifan lokal dalam pengelolaan sumber daya pesisir di Kabupaten Raja Ampat [thesis]. Semarang: Universitas Diponegoro.

Hickey FR, Johannes RE. 2002. Recent evolution of village-based marine resource management in Vanuatu. SPC Traditional Marine Resource Management and Knowledge Information Bulletin 14:8-12.

Johannes RE. 1978. Traditional marine conservation methods in Oceania and their demise. Annual Reviews of Ecology and Systematics 9:349-364.

Lam M. 1998. Consideration of customary marine tenure system in the establishment of marine protected areas in the South Pacific. Ocean \& Coastal Management 39:97-104. http://dx.doi.org/10.1016/S0964-5691(98) 00017-9.

Larsen SN, Leisher C, Mangubhai S, Muljadi A, Tapilau R. 2011. Laporan Penilaian Desa Pesisir di Kabupaten Raja Ampat, Papua Barat, Indonesia. Sorong: The Nature Conservancy.

Mansoben JR. 2003. Konservasi sumber daya alam Papua, ditinjau dari aspek budaya. Jurnal Antropologi 2(4):1-12.

Mansoben JR. 2010. Kebudayaan dan pembangunan dalam kerangka otonomi khusus. In: Simposium Nasional Papua "Menuju Pembangunan Berbasis Masyarakat yang berkelanjutan"; 2010 Jakarta, April 7-9, 2010. Pp1-14.

McLeod E, Szuster B, Salm R. 2009. Sasi and marine conservation in Raja Ampat, Indonesia. Coastal Management 37(6):656-676. http://dx.doi.org/10.1080/ 08920750903244143.

Monk K, de Fretes Y, Reksodiharjo-Lilley G. 1997. The ecology of Nusa Tenggara and Maluku. The ecology of Indonesia Series, Volume V. EMDI
Muehlig-Hofmann A. 2007. Traditional authority and community leadership: key factors in community-based marine resource management and conservation. SPC Traditional Marine Resource Management and Knowledge Information Bulletin 21:31-44.

Mustaghfirin et al. 2012. Buku 2 Rencana Pengelolaan Taman Pulau-pulau Kecil dan Daerah (TPPKD) Raja Ampat: Data \& Analisis. Waisai: Pemerintah Daerah Kabupaten Raja Ampat.

Nikijuluw VPH. 1994. Sasi sebagai suatu pengelolaan sumberdaya berdasarkan komunitas (PSBK) di Pulau Saparua, Maluku. Jurnal Penelitian Perikanan Laut 93:79-92.

Novaczek I, Harkes IH, Sopacua J, Tatuhey M. 2001. An Institutional Analysis of Sasi Laut in Maluku, Indonesia, Penang: ICLARM Technical Report No. 59

Samoilys Ma et al. 2007. Effectiveness of five small Philippines' coral reef reserves for fish populations depends on site-specific factors, particularly enforcement history. Biological Conservation 136(4):584-601. http://dx.doi.org/10.1016/j.biocon.2007.01.003.

Thorburn CC. 2000. Changing customary marine resource management practice and institutions: the case of sasilola in the Kei Islands, Indonesia. World Development 28(8):1461-1479. http://dx.doi.org/10.1016/S0305750X(00)00039-5.

Tuhulele P. 2013. Kearifan lokal masyarakat adat Maluku dalam perlindungan dan pengelolaan lingkungan hidup. Kompilasi pemikiran tentang dinamika hukum dalam masyarakat (memperingati Dies Natalis ke-50 Universitas Pattimura tahun 2013). Http://fhukum. Unpatti.ac.id/artikel/lingkungan-hidup-pengelolaansda-dan-perlindungan-hak-hak-adat/269-kearifan-lokalmasyarakat-adat-maluku-dalam-perlindungan-danpengelolaan-lingkungan-hidup. [14 November 2013].

Wahyono A et al. 2000. Hak Ulayat Laut di Kawasan Timur Indonesia. Yogyakarta: Media Pressindo, Yayasan Adikarya Ikapidan, The Ford Foundation.

Wahyudi Y. 2003. Sistem sosial ekonomi dan budaya masyarakat pesisir. Makalah pada pelatihan pengelolaan kawasan konservasi perairan. Bogor: Diklat Kehutanan Bogor.

Weiant P, Aswani S. 2006. Early effects of a communitybased marine protected area on the food security of participating households. SPC Traditional Marine Resource Management and Knowledge Information Bulletin 19:16-31. 